\title{
Ascorbic acid concentration of human fetal tissues in relation to fetal size and gestational age
}

\author{
By SUNITA ZALANI, R. RAJALAKSHMI AND L. J. PAREKH \\ Department of Biochemistry, Faculty of Science, M.S. University, Baroda, India
}

(Received 5 October 1988 - Accepted 20 December 1988)

\begin{abstract}
1. Studies were carried out on the distribution of ascorbic acid in human fetal tissues with the progress of gestation.

2. Fetuses and stillborn babies varying in gestational age from 12 to 38 weeks were obtained from various Baroda hospitals. Ascorbic acid levels were determined in selected tissues : brain, adrenal, liver, kidney, lung, heart and placenta.

3. Ascorbic acid concentration in the brain was higher than that in the adrenal at all gestational ages, suggesting the importance of this vitamin in brain development. The concentrations of this vitamin in liver, kidney, lung and placenta were comparable, but that in the heart tended to be lower. In all the tissues, there was a fall in ascorbic acid during late gestation. However, the levels in tissues of stillborn babies were higher than those reported for adults.
\end{abstract}

It is well known that reproductive performance imposes physiological and nutritional stress on the maternal organism. When the maternal diet is already poor, it is likely to become more so with the advent of pregnancy and lactation. The demands for ascorbic acid are very high during reproduction as the fetus is born with a store of $700-1000 \mathrm{mg}$ of this vitamin (Rajalakshmi et al. 1974).

It is also known that the placenta has a high concentration of ascorbic acid (Subbulakshmi, 1970) and that cord blood has a higher concentration of ascorbic acid than maternal blood (Vobecky et al. 1982). This was also found to be true of poorly nourished women with low intakes of ascorbic acid in previous studies in this laboratory (Rajalakshmi \& Ramakrishnan, 1969). The latter study showed the satisfactory transfer of ascorbic acid to infants even by mothers on low intakes of the vitamin. A question arises as to the status of the growing fetus with regard to ascorbic acid. The present studies are concerned with the distribution of ascorbic acid in human fetal tissues in relation to gestational age and fetal growth.

\section{MATERIALS AND METHODS}

Studies were made on 121 fetuses obtained from three hospitals in Baroda. Fetuses less than 20-22 weeks were largely obtained by medical termination of pregnancy, whereas those above 20-22 weeks were largely derived from spontaneous abortions and stillbirths. They were immediately kept in ice after abortion, transported to the laboratory, dissected and the tissues taken for analysis.

Gestational age was taken as menstrual age (as reported by the mother after careful questioning) minus 2 weeks to allow for ovulation. Ascorbic acid levels were determined in selected fetal tissues : brain, adrenals, kidney, liver, lung, heart and placenta. The method used for the estimation of total ascorbic acid was the dinitrophenyl hydrazine procedure (Roe \& Kuether, 1943). DNA was estimated by the procedure of Schneider (1957). Student's $t$ test was used to determine the significance of differences between groups. 


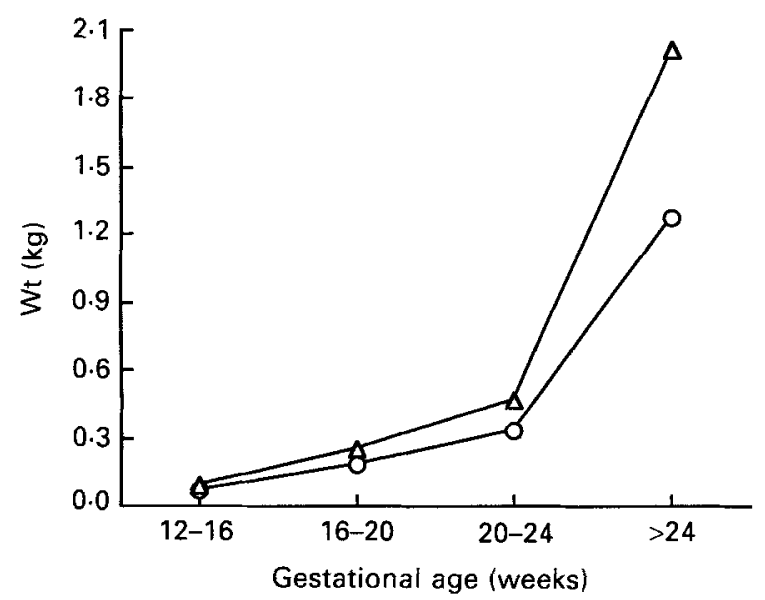

Fig. 1. Fetal weight with progress of gestation for growth-normal $(\triangle)$ and growth-retarded $(O)$ human fetuses (for details of fetuses, see p. 601). Numbers of observations for the different age groups are given in parentheses. Growth-normal: 12-16 weeks (24), 16-20 weeks (48), $20-24$ weeks (12), > 24 weeks (10). Growth-retarded: 12-16 weeks (4), 16-20 weeks (8), 20-24 weeks (11), > 24 weeks (2).

\section{RESULTS}

Fetal weights were found to increase significantly with the progress of gestation; they were less than those reported for corresponding gestational age in the West (Gruenwald, 1966; Thompson et al. 1968), but the values for weeks 12-16 and 16-20 compare with those reported by others in this country (Iyengar \& Apte, 1972; Lakshminarayan et al. 1974).

When fetal weights were considered as a percentage of expected weight for gestational age using Widdowson's (1968) norms, they were classified as growth-normal and growthretarded, using a cutoff point of $60 \%$. The differences in fetal weights between growthnormal and growth-retarded fetuses are shown in Fig. 1. The growth-normal fetuses exhibited higher tissue weights than growth-retarded fetuses, which is consistent with the differences in their body-weights.

The ascorbic acid concentration in fetal tissues with the progress of gestation is presented in Table 1. The pattern for adrenal and brain tissues was unexpected, the latter being greater than the former. This was true for all gestational ages. The brain values were very high and in the range $0.104-0.785 \mathrm{mg} / \mathrm{g}$ during $12-20$ weeks of gestational age.

Ascorbic acid concentration showed a decrease during late gestation in all tissues, the decrease being significant in the case of brain and adrenals. The decrease in concentration of this vitamin in the lung was at an earlier age.

The growth-retarded fetuses showed a significantly lower concentration of ascorbic acid than the growth-normal fetuses during weeks 12-16 of gestation in the brain, liver and kidney, but a similar pattern was not observed thereafter (Table 2).

\section{DISCUSSION}

Brain ascorbic acid levels were greater than adrenal ascorbic acid levels at all gestational ages. The mean moisture content of the brain at weeks 16-20 of gestation was found to be $909 \mathrm{mg} / \mathrm{g}$ and protein concentration was $44 \mathrm{mg} / \mathrm{g}$, so that non-protein solids accounted for $47 \mathrm{mg} / \mathrm{g}$. Ascorbic acid appeared to form $1 \%$ of non-protein solids.

The ascorbic acid levels in the brain declined significantly after 32 weeks of gestation. Even in stillborn babies, ascorbic acid in the brain remained higher than those reported for 
Table 1. Ascorbic acid concentration in human fetal $\dagger$ tissues with the progress of gestation $(\mathrm{mg} / \mathrm{g})$

(Mean values with their standard errors; no. of observations in parentheses)

\begin{tabular}{|c|c|c|c|c|c|c|c|c|}
\hline \multirow{2}{*}{$\begin{array}{l}\text { Gestational } \\
\text { age (weeks)... }\end{array}$} & $<16$ & \multicolumn{2}{|c|}{$16-20$} & \multicolumn{2}{|c|}{$20-24$} & \multicolumn{2}{|c|}{$28-32$} & $>32$ \\
\hline & Mean SE & Mean & $\mathrm{SE}$ & Mean & $\mathrm{SE}$ & Mean & $\mathrm{SE}$ & Mean \\
\hline Brain & $\begin{array}{c}0.349 \quad 0.024 \\
(27)\end{array}$ & $\begin{array}{r}0.408 \\
\quad(43)\end{array}$ & 0.030 & $\begin{array}{l}0.423 \\
(23)\end{array}$ & 0.037 & $\begin{array}{r}0.525^{* * * *} \\
(5)\end{array}$ & 0.050 & $\begin{array}{c}0.2544_{(7)}^{0.057} \\
\end{array}$ \\
\hline Adrenals & $\begin{array}{c}0.224 \quad 0 \cdot 020 \\
(27)\end{array}$ & $\begin{array}{r}0.206 \\
(43)\end{array}$ & 0.013 & $\begin{array}{r}0.232 \\
(23)\end{array}$ & $0 \cdot 015$ & $\begin{array}{r}0 \cdot 295^{*} \\
(5)\end{array}$ & $0 \cdot 060$ & $\begin{array}{c}0.142 \quad 0 \cdot 020 \\
(7)\end{array}$ \\
\hline Liver & $\begin{array}{c}0.1970 .018 \\
(27)\end{array}$ & $\begin{array}{r}0 \cdot 166^{* * *} \\
(46)\end{array}$ & 0.012 & $\begin{array}{r}0.229 \\
(23)\end{array}$ & 0.018 & $\begin{array}{r}0.159 \\
(5)\end{array}$ & 0.039 & $\begin{array}{c}0.1140 .016 \\
(7)\end{array}$ \\
\hline Kidney & $\begin{array}{c}0.1970 \cdot 015 \\
(27)\end{array}$ & $\begin{array}{r}0.186 \\
(32)\end{array}$ & 0.014 & $\begin{array}{r}0.221 \\
(12)\end{array}$ & $0 \cdot 028$ & $\begin{array}{r}0.162 \\
(5)\end{array}$ & $0 \cdot 024$ & $\begin{array}{c}0.110 \quad 0.035 \\
\text { (7) }\end{array}$ \\
\hline Lung & $\begin{array}{c}0.210 \quad 0.020 \\
\text { (11) }\end{array}$ & $\begin{array}{l}0 \cdot 184 \\
\quad(32)\end{array}$ & $0 \cdot 011$ & $\begin{array}{r}0 \cdot 220^{* * * *} \\
\text { (9) }\end{array}$ & $0 \cdot 027$ & $\begin{array}{r}0.111 \\
(5)\end{array}$ & 0.020 & $\begin{array}{c}0.096 \quad 0.019 \\
\text { (7) }\end{array}$ \\
\hline Heart & $\begin{array}{c}0.110 \quad 0.009 \\
\text { (11) }\end{array}$ & $\begin{array}{r}0.111 \\
(25)\end{array}$ & 0.008 & $\begin{array}{r}0.122 \\
(9)\end{array}$ & $0 \cdot 008$ & $\begin{array}{r}0 \cdot 121 \\
(5)\end{array}$ & $0 \cdot 019$ & $\begin{array}{c}0.0790 .017 \\
\text { (7) }\end{array}$ \\
\hline Placenta & $\begin{array}{c}0.157 \quad 0.027 \\
(6)\end{array}$ & $\begin{array}{r}0 \cdot 166 \\
(19)\end{array}$ & 0.011 & $\begin{array}{r}0 \cdot 161 \\
(9)\end{array}$ & $0 \cdot 016$ & $\begin{array}{r}0.197 \\
(5)\end{array}$ & 0.029 & $\begin{array}{c}0.150 \quad 0.050 \\
\text { (2) }\end{array}$ \\
\hline
\end{tabular}

Mean values were significantly different from those for the subsequent gestational age-group: ${ }^{*} P<0 \cdot 05$, *** $P<0.001$.

$\uparrow$ For details of fetuses, see p. 601.

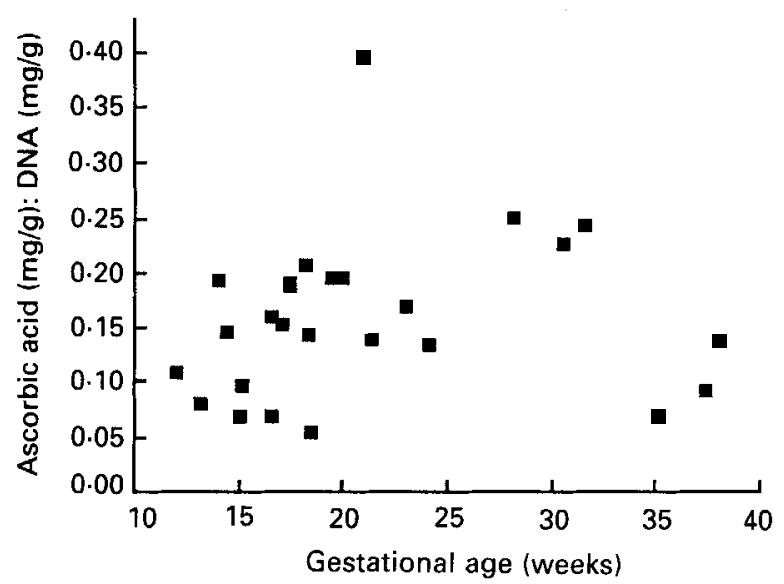

Fig. 2. Human fetal brain ascorbic acid: DNA with progress of gestation (for details of fetuses, see p. 601 )

adults (Hornig, 1975). Similar observations have been made by Adlard et al. (1974), who reported that forebrain ascorbic acid levels in full-term babies (37-42 weeks gestational age) were at least three times higher than the adult levels. In this connection, it is known that the rate of decrease in ascorbic acid is greatest during early life, but continues to some extent into adult life (Schaus, 1957).

Autoradiographical studies by Hammarstrom (1966) on pregnant mice have confirmed that the fetal brain at full term concentrates ascorbic acid up to 100 -fold from maternal 
Table 2. Ascorbic acid concentration in tissues of growth-retarded $(G R)$ and growthnormal $(G N)$ human fetuses $(\mathrm{mg} / \mathrm{g}) \dagger$

(Mean values with their standard errors; no. of observations in parentheses)

\begin{tabular}{|c|c|c|c|c|c|}
\hline \multirow{2}{*}{$\begin{array}{l}\text { Gestational } \\
\text { age (weeks) ... }\end{array}$} & & $12-16$ & $16-20$ & $20-24$ & $28-38$ \\
\hline & & Mean & Mean & Mean & Mean \\
\hline \multirow[t]{2}{*}{ Brain } & GR & $\begin{array}{c}0.226 * * \\
\text { (4) }\end{array}$ & $\begin{array}{c}0.399 \quad 0.093 \\
(5)\end{array}$ & $\begin{array}{c}0.4370 .058 \\
\text { (11) }\end{array}$ & $\begin{array}{c}0.4530 .152 \\
(3)\end{array}$ \\
\hline & GN & $\begin{array}{c}0.3690 .025 \\
\text { (23) }\end{array}$ & (38) & (12) & (9) \\
\hline \multirow[t]{2}{*}{ Adrenals } & GR & $\begin{array}{c}0.172 \quad 0.042 \\
\text { (4) }\end{array}$ & $\begin{array}{c}0.1870 .015 \\
(7)\end{array}$ & $\begin{array}{c}0.228 \quad 0.022 \\
\text { (11) }\end{array}$ & $\begin{array}{c}0.180 \quad 0.022 \\
(3)\end{array}$ \\
\hline & GN & $\begin{array}{c}0.2330 .023 \\
(23)\end{array}$ & $\begin{array}{c}0.210 \quad 0.014 \\
(36)\end{array}$ & $\begin{array}{c}0.237 \quad 0.022 \\
(12)\end{array}$ & $\begin{array}{c}0.2140 .046 \\
(9)\end{array}$ \\
\hline \multirow[t]{2}{*}{ Liver } & GR & $\begin{array}{c}0 \cdot 106 * * * 6^{*} 0.005 \\
\text { (4) }\end{array}$ & $\begin{array}{c}0.180 \quad 0-028 \\
(7)\end{array}$ & $\begin{array}{c}0.2490 .021 \\
(1 \mathrm{I})\end{array}$ & $\begin{array}{c}0.155 \quad 0.038 \\
(3)\end{array}$ \\
\hline & GN & $\begin{array}{c}0.210 \\
(23)\end{array}$ & $\begin{array}{c}0.1630 .013 \\
(39)\end{array}$ & $\begin{array}{c}0.2110 .029 \\
(12)\end{array}$ & $\begin{array}{c}0.1310 .020 \\
(9)\end{array}$ \\
\hline \multirow[t]{2}{*}{ Kidney } & GR & $\begin{array}{c}0.149^{*} \\
\text { (4) }\end{array}$ & $\begin{array}{c}0.180 \quad 0.048 \\
0.187^{(5)}\end{array}$ & $\begin{array}{c}0.193 \quad 0.032 \\
(6)\end{array}$ & $\begin{array}{c}0.1420 .030 \\
\text { (3) }\end{array}$ \\
\hline & $\mathrm{GN}$ & $c^{0.206} 0.017$ & $\begin{array}{c}0.1870 .015 \\
(27)\end{array}$ & $\begin{array}{c}0.250 \quad 0.046 \\
(6)\end{array}$ & $\begin{array}{c}0.1290 .017 \\
(9)\end{array}$ \\
\hline \multirow[t]{2}{*}{ Lung } & GR & $\begin{array}{c}0 \cdot 2844_{(2)}^{0 \cdot 104} \\
\end{array}$ & $\begin{array}{c}0.168 \quad 0.024 \\
(7)\end{array}$ & $\begin{array}{c}0.245 \quad 0.029 \\
(5)\end{array}$ & $\begin{array}{c}0.108 \quad 0.036 \\
\text { (3) }\end{array}$ \\
\hline & GN & $\begin{array}{c}0.1940 .019 \\
\text { (9) }\end{array}$ & $\begin{array}{c}0.1890 .011 \\
(25)\end{array}$ & $\begin{array}{c}0.1880 .048 \\
(4)\end{array}$ & $\begin{array}{c}0.1000 .015 \\
(9)\end{array}$ \\
\hline \multirow[t]{2}{*}{ Heart } & GR & $\begin{array}{c}0.1160 .016 \\
(2)\end{array}$ & $\begin{array}{c}0.104 \quad 0.020 \\
(6)\end{array}$ & $\begin{array}{l}0.127 \quad 0.014 \\
0.117^{(5)}\end{array}$ & $\begin{array}{c}0.129 \quad 0.037 \\
(3)\end{array}$ \\
\hline & GN & $\begin{array}{c}0 \cdot 108 \\
(9)\end{array}$ & $\begin{array}{c}0.1130 .009 \\
\text { (19) }\end{array}$ & $0.117 \underset{(4)}{0.008}$ & $\begin{array}{c}0.090 \quad 0.017 \\
(9)\end{array}$ \\
\hline \multirow[t]{2}{*}{ Placenta } & GR & - & $\begin{array}{c}0.151 \quad 0-011 \\
(4)\end{array}$ & $\begin{array}{c}0.151 \quad 0.010 \\
(2)\end{array}$ & $\begin{array}{c}0.155 \quad 0 \cdot 045 \\
\text { (2) }\end{array}$ \\
\hline & GN & $\begin{array}{c}0.157 \quad 0.027 \\
(6)\end{array}$ & $\begin{array}{c}0.1700 .014 \\
(15)\end{array}$ & $\begin{array}{c}0.1660 .019 \\
(7)\end{array}$ & $\begin{array}{c}0 \cdot 1950.030 \\
(5)\end{array}$ \\
\hline
\end{tabular}

Mean values were significantly different from GN values: ${ }^{*} P<0.05,{ }^{* *} P<0.01,{ }^{* * *} P<0.001$.

$\uparrow$ For details of fetuses, see p. 601.

plasma. The following roles have been designated for ascorbic acid in the brain: $(a)$ it is essential for catecholamine metabolism and its regulation, particularly, as a cofactor of dopamine $\beta$-mono-oxygenase (dopamine $\beta$-hydroxylase, EC 1.14.17.1) (Friedman \& Kaufman, 1965). Cerebral regions in rat brain which have high concentrations of catecholamines often have correspondingly high ascorbate levels although no direct correlation has been shown (Milby et al. 1982); $(b)$ there is speculation that ascorbic acid and its oxidized forms are regulators of cell division (Edgar, 1970).

The high ascorbate content of the immature brain may have an anatomical basis. With the progress of myelination, it is possible that the ascorbic acid compartment, i.e. neurons, is diluted because of glial growth and myelination. Shimizu et al. (1960) have observed histochemically that brain ascorbic acid was predominantly localized in neuronal cell bodies, which supports this possibility. The ascorbic acid $(\mathrm{mg} / \mathrm{g})$ : DNA $(\mathrm{mg} / \mathrm{g})$ ratio in the fetal brain with progress of gestation is shown in Fig. 2; the fall in the fetuses of weeks 35-38 from the ratio in fetuses of weeks 28-31 was significant $(P<0.01)$.

The adrenal ascorbic acid levels declined significantly after 32 weeks of gestation. The 
bulk of the fetal gland is composed of the fetal zone, overlying which is a thin rim of cells which come to constitute the definitive or adult cortex of the gland after birth. The fetal zone begins to degenerate shortly before birth (Lanman, 1962). The fetal zone, the placenta and the fetal liver function as an integrated unit to produce and metabolize the major steroid hormones necessary for proper fetal development and maintenance of pregnancy (Yeasting, 1986). In the adrenals, both cortex and medulla require ascorbic acid for the synthesis of corticosteroids and catecholamines respectively.

In the case of liver, lung, kidney and heart, ascorbic acid levels tend to decrease after 24 weeks of gestation and to show a further decrease at term but the differences were not significant, perhaps because of wide intragroup variation and sample size. It is known that ascorbic acid exists in greater concentrations in embryonic tissues where synthetic processes occur with intensity. The ascorbic acid concentrations in these tissues are comparable to those reported by Yavorsky et al. (1937) and Bessey \& King (1933). Placental ascorbic acid levels were comparable to those reported by Toverud et al. (1950).

Placental ascorbic acid concentrations remained constant and were comparable to those of liver and kidney during early pregnancy. Studies in the rat have suggested that at all times during gestation, the placenta has greater ability to concentrate labelled ascorbic acid than the fetus (Rosso \& Norkus, 1976). It is thought that the placenta may also actively transport ascorbic acid by a mechanism similar to that for amino acids (Dancis et al. 1968; Longo et al. 1973).

Growth retardation was associated with a significant decrease in ascorbic acid concentration in brain, liver and kidney during weeks $12-16$ of gestation.

In conclusion, the present studies indicate that human fetal brain has a higher concentration of ascorbic acid than the adrenals. The ascorbic acid concentrations in the liver, kidney, lung and placenta were comparable while those in the heart tended to be less. In the case of all the tissues, a decline was found after 32 weeks of gestation but it was significant only in the case of the brain and adrenals. These studies point to the importance of ascorbic acid for the functional maturity of the fetal brain. The marked differences in the concentrations in the brain and adrenals of the human fetus emphasize the need for comparative studies on species differences with regard to this aspect.

\section{REFERENCES}

Adlard, B. P. F., Desouza, S. W. \& Moon, S. (1974). Ascorbic acid in fetal human brain. Archives of Disease in Childhood 49, 278-282.

Bessey, O. A. \& King, C. G. (1933). The distribution of vitamin C in plant and animal tissues and its determination. Journal of Biological Chemistry 103, 687-698.

Dancis, J., Money, W. L., Springer, D. \& Levitz M. (1968). Transport of amino acids by placenta. American Journal of Obstetrics and Gynecology 101, 820-829.

Edgar, J. A. (1970). Dehydroascorbic acid and cell division. Nature 227, 24-26.

Friedman, S. \& Kaufman, S. (1965). 3,4-Dihydroxyphenylethylamine $\beta$-hydroxylase. Journal of Biological Chemistry 240, 4763-4773.

Gruenwald, P. G. (1966). Growth of the human fetus: normal growth and its variations. American Journal of Obstetrics and Gynecology 94, 1112-1119.

Hammarstrom, L. (1966). Autoradiographic studies on the distribution of $\mathrm{C}^{14}$ labelled ascorbic acid and dehydroascorbic acid. Acta Physiologica Scandinavica 70, Suppl. 289, 84 pp.

Hornig, D. (1975). Distribution of ascorbic acid, metabolites and analogues in man and animals. Annals of the New York Academy of Sciences 258, 103-118.

Iyengar, L. \& Apte, S. V. (1972). Nutrient stores in human foetal livers. British Journal of Nutrition 27, 313-317.

Lakshminarayan, P., Nagaswamy, S. \& Balagopala, R. V. (1974). Foetal growth as assessed by anthropometric measurements. Indian Pediatrics 11, 803-810.

Lanman, J. (1962). An interpretation of human foetal adrenal structure and function. In The Human Adrenal Cortex, pp. 547-557 [A. R. Currie, T. Symington and J. K. Grant, editors]. Baltimore: Wiliams and Wilkins.

Longo, L. D., Yuen, P.\& Gusseck, D. J. (1973). Anaerobic, glycogen-dependent transport of amino acids by the placenta. Nature 243, 531-533. 
Milby, K., Oke, A. \& Adams, R. N. (1982). Detailed mapping of ascorbate distribution in rat brain. Neuroscience Letters 28, 15-20.

Rajalakshmi, R. \& Ramakrishnan, C. V. (1969). Gestation and Lactation Performance in Relation to Nutritional Status. Terminal Report of PL 480 Research Project FG-IN-224, Biochemistry Department, M.S. University, Baroda.

Rajalakshmi, R., Subbulakshmi, G. \& Kothari, B. (1974). Ascorbic acid metabolism during pregnancy and lactation. Baroda Journal of Nutrition 1, 117-134.

Roe, J. H. \& Kuether, C. A. (1943). The determination of ascorbic acid in whole blood and urine through the 2,4dinitrophenylhydrazine derivative of dehydro-ascorbic acid. Journal of Biological Chemistry 147, $399-407$.

Rosso, P. \& Norkus, E. (1976). Prenatal aspects of ascorbic acid metabolism in the albino rat. Journal of Nutrition 106, 767-770.

Schaus, R. (1957). The ascorbic acid content of human pituitary, cerebral cortex, heart and skeletal muscle and its relation to age. American Journal of Clinical Nutrition 5, 3941.

Schneider, W. C. (1957). Determination of nucleic acids in tissues by pentose analysis. In Methods in Enzymology, vol. 3, pp. 680-684 [S. P. Colowick and N. O. Kaplan, editors]. New York: Academic Press.

Shimizu, N., Matsunami, T. \& Onishi, S. (1960). Histochemical demonstration of ascorbic acid in the locus coeruleus of the mammalian brain. Nature 186, $479-480$.

Subbulakshmi, G. (1970). Studies on pregnancy and lactation. PhD Thesis, M.S. University, Baroda, India.

Thompson, A. M., Billewicz, W. Z. \& Hytten, F. E. (1968). The assessment of fetal growth. Journal of Obstetrics and Gynaecology of the British Commonwealth 75, 903-916.

Toverud, K. U., Stearns, G. \& Macy, I. G. (1950). Maternal nutrition and child health. Bulletin of the National Academy of Sciences no. 123. Washington DC: National Academy of Sciences.

Vobecky, J. S., Vobecky, J., Shapcott, D., Demers, P. P., Cloutier, D., Blanchard, R. \& Fisch, C. (1982). Biochemical indices of nutritional status in maternal, cord and early neonatal blood. American Journal of Clinical Nutrition 36, 630-642.

Widdowson, E. M. (1968). Growth and composition of the fetus and newborn. In Biology of Gestation, vol. 2. pp. 1-49 [N. S. Assali, editor]. New York: Academic Press.

Yavorsky, M., Almaden, P. \& King, C. G. (1937). The vitamin C content of human tissues. Journal of Biological Chemistry 106, 525-529.

Yeasting, R. (1986). Selected morphological aspects of human suprarenal glands. In The Adrenal Gland, pp. 45-64 [P. J. Murlow, editor]. New York: Elsevier. 